SECTION 13. Geography. History. Oceanology. Meteorology.

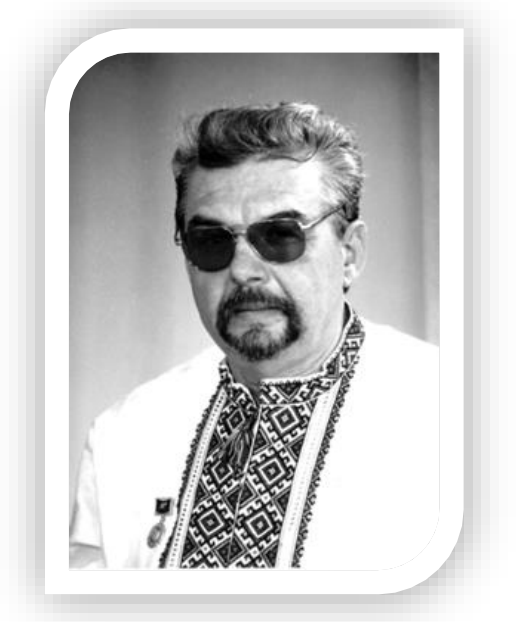

Tatarinov Sergey Iosifovich candidate of historical Sciences, associate Professor, corresponding member of International Academy of

Theoretical \& Applied Sciences, Educational and Scientific Professional Pedagogical Institute of Ukrainian Engineering and Pedagogical

Academy

tatbronza@yandex.ua

\title{
THE DONBASS DISTRICT COUNCILS' CHARITY IN THE DEVELOPMENT OF MEDICINE IN THE 2ND PART OF THE 19TH - EARLY 20TH CENTURIES.
}

Abstract: The role of the Bakhmut and Mariupol district councils in creating and funding of county's and city's hospitals, medical staff and the conditions of its work, maintenance, treatment of patients are analyzed in the article.

Key words: Zemstvo, public, hospital, doctor, paramedic, medicine.

\section{БЛАГОТВОРИТЕЛЬНОСТЬ УЕЗДНЫХ ЗЕМСТВ ДОНБАССА В РАЗВИТИИ МЕДИЦИНЫ ВО 2-Й ПОЛОВИНЕ 19 - НАЧАЛЕ 20 СТОЛЕТИЙ.}

Аннотация: В статье анализируются роль Бахмутского и Мариупольского уездных земств в создании, финансировании уездных и городских больнии, состав медииинского персонала и условия его труда, содержание, лечение пациентов.

Ключевые слова: земство, гласный, больница, врач, фельдшер, лекарства.

\section{УДК 908}

\section{БЛАГОДІЙНІСТЬ ПОВІТОВИХ ЗАМСТВ ДОНБАСУ У РОЗВИТКУ МЕДИЦИНИ У 2-й ПОЛОВИНІ 19 - НА ПОЧАТКУ 20 СТ.}

Актуальність дослідження. Україна за останні 20 років пережила болісний соціально-економічний злам від «розвиненого соціалізму» до дикого капіталізму. Різке майнове розшарування населення, зубожіння, зростання бідності знову вимагають від суспільства використання позитивного досвіду меценатства та благодійності часів існування земських установ.

Оскільки Україна стала на шлях розбудови громадянського суспільства, постало завдання поліпшення соціально-побутових умов, підвищення загального рівня життя громадян. Останні роки спостерігається зниження рівня охорони здоров'я населення, ставлення до нього як до життєвої цінності.

Започаткована у 2011 р. реформа охорони здоров’я має на увазі вдосконалення якості медичної допомоги на первинному рівні, створення потужних медичних округів з надання спеціалізованої стаціонарної допомоги, підготовку нової категорії «сімейних» лікарів за зразком земського досвіду. 
Вирішення нагальних питань покладається на місцеву владу, яка, зважаючи на перспективи подальшого розвитку охорони здоров'я, мусить вміло поєднувати ефективні організаційно-медичні технології $з$ оптимальними витратами.

Цілком розумним $є$ звернення до досвіду, набутого земськими установами у справі розвитку медичного обслуговування населення.

Метою дослідження $\epsilon$ аналіз діяльності земських установ Донбасу по розвитку медичної допомоги у повітових містах, видів благодійності повітових земств та міських Дум.

Історіографія питання. В.І. Ленін-Ульянов писав про земську реформу 1864 р., як одну «... из тех уступок, которые отбила у самодержавного правительства волна общественного возбуждения и революционного натиска» [1, с.33].

Питанню розвитку медичної допомоги як прояву земської діяльності та благодійності було присвячено багато дореволюційних досліджень.

Є.А. Осипов, І.В. Попов, П.І. Куркін відзначили, що земська медицина повинна спрямувати роботу на сільське населення [21.

А.В. Абрамов звернув увагу на зміну кількості земських медичних установ, проблеми фінансування та забезпечення, труднощі практичної діяльності [3]

Б.Б. Веселовський, Г.С. Львов і Т.І. Полнер писали про досягнення земств у медицині[4]

Важливе значення для розвитку земської медичної благодійності, поширення досвіду діяльності лікарів мали періодичні видання «Архив судебной медицины и общественной гигиены», «Земский врач», «Московская медицинская газета», «Врач», «Русский врач», «Журнал общества русских врачей в память Н.И. Пирогова», «Общественный врач» и др.; передовые медицинские общества: «Общество русских врачей в Москве», «Общество врачей в Казани», «Общество русских врачей в память Н.И. Пирогова».

Вперше у радянські часи С.М. Ігумнов за участі лікарів, які мали досвід роботи в земстві, видав наукову працю з проблем становлення медицини як науки, впровадженим земською медициною нових підходів у лікуванні, аналізувалися особливості розвитку земської медицини в українських губерніях [5].

Історико-медичні дослідження з розвитку земської медицини в Україні продовжилися у 50-ті pp. [6]

У 60-70- х pp. XX ст. спостерігалося вивчення особливостей становлення земської медицини, спеціалізації лікарів, надання медичної допомоги певним категоріям населення, санітарної організації [7].

Були захищені дисертації, присвячені історії земств [8].

У незалежній Україні досліджуються питання формування і розвитку земської медицини у 1865-1914 pp. [9].

У історичній науці ствердилося сприйняття земської медицини як суспільного феномену благодійності, предметом дисертаційних досліджень $є$ практична діяльність земств, розробки набувають практичне значення [10].

Основний зміст. Як витікало з Положення 1864 р. серед «необов'язкових» функцій земських установ було «попечение в пределах, законом определенных и преимущественно в хозяйственном отношении, о народном здравии».

Закон зобов'язував земства утримувати тільки передані їм заклади колишнього «Приказа общественного призрения», приймати заходи щодо віспощеплення. Певної регламентації діяльності земств по наданню медичної допомоги селянам не існувало.

Вперше аналіз земської медицини зроблено 3.Г. Френкелєм.

\begin{tabular}{|l|c|c|}
\hline & $\mathbf{1 8 7 0}$ г. & $\mathbf{1 9 1 0}$ г. \\
\hline Число врачей в земских губерниях & 610 & 3082 \\
\hline В т.ч. в сельской местности & 243 & 2335 \\
\hline Число врачебных участков & 530 & 2686 \\
\hline
\end{tabular}


ISPC «Scientific technologies of the future», 28.02.2014

\begin{tabular}{|l|c|c|}
\hline $\begin{array}{l}\text { Площадь среднего врачебного участка (в квадратных } \\
\text { верстах) }\end{array}$ & 4860 & 930 \\
\hline Радиус среднего врачебного участка (в верстах) & 39 & 17 \\
\hline $\begin{array}{l}\text { Количество населения на 1 врачебный участок (в } \\
\text { среднем в тысячах) }\end{array}$ & 95 & 28 \\
\hline Число больничных коек в среднем на 10 000 населения & 1,5 & 4,8 \\
\hline Число самостоятельных фельдшерских пунктов & 1350 & 2620 \\
\hline
\end{tabular}

3. Г. Френкель писав «...если в деле народного образования земство могло идти путями уже давно пройденными нашими западными соседями, ... то в области создания общественной организации обеспечения сельскому населению современной научной медицинской помощи земство не имело никаких готовых образцов на Западе, которыми можно было в той или иной мере руководствоваться. И заслуга русского земства состояла в том..., что оно сумело создать совершенно новую оригинальную по своей постановке и строю систему общественного обслуживания населения медицинской помощью и выработало в связи с этой общедоступной медицинской помощи населению новые пути для осуществления общественно-санитарных задач. В этом сказалось наиболее ярко проявление творческой способности русского земского самоуправления - устроительная сила общественной самодеятельности» $[11, c .5]$.

Велику частину населення Катеринославської губернії складали селяни. Населені пункти в усіх повітах були розташовані по усій території нерівномірно. Міста повітів розташовувалися не в центрі повіту і часто були недосяжні для жителів навколишніх сіл.

Ці обставини мали вплив на стан здоров'я і рівень вченості місцевого населення, лікарні існували тільки в містах і в окремих селах.

Нестача медиків, відсутність фінансування, станові обмеження не сприяли розвитку охорони здоров'я сільського населення губернії.

До 1860 р. у Катеринославській губернії було повітових лікарів 8, міських 7. Приватних лікарів при дворянах 4, фармацевт - 1, повитух 10, фельдшерів лікарень 11, учнів лікарів 13 [12].

Невелика гарнізонна лікарня існувала у Маріуполі «военно-временный лазарет был предназначен для нижних чинов местной военной команды».

У діяльності земств повітів Донеччини виділяються певні етапи.

Перший (1865-1870рр.) пов'язаний з проблемами передачі земству лікарень i усієї "лікарської частини" від колишнього Наказу громадського піклування. Були зроблені кроки по облаштуванню цих лікарень і поширенню широкої медичної допомоги селянам через запрошення, підготовку фельдшерів, відкриття фельдшерських пунктів.

В 1864 р. в Бахмутській лікарні лікувалося 546 осіб, видужало 464, померло 30. В тюремній лікарні знаходилося 74 пацієнти, померло 9 [13].

Після 1865 р. лікарня знаходилася за містом у великій двоповерховій будівлі (нижній поверх був кам'яний, верхній-дерев'яний) і двоповерховому флігелі [14].

В штаті Бахмутської городової лікарні в 1864-1875 pp. працювали лікар Микола Твердохлєбов, що закінчив Харківський університет, лікар надвірний радник Микола Масловський, закінчив той же університет.

Допомогу по пологах надавали вдома старша повивальна бабця Ганна Лентовська, з дворян, закінчила курси при Білостокському монастирі, молодша повивальна бабця Варвара Зінченко, 3 поповен, свідоцтво на право заняття акушерством отримала в Петербурзі.

Другий етап розвитку повітової медицини (1870-80рр.) характеризується введенням "виїзної системи" медичного обслуговування населення професійними 
лікарями, які періодично об'їжджали повіт. «Помимо деятельности на врачебном пункте, в амбулатории и в собственной больнице земский врач обязан выезжать в те деревни, где обнаруживаются эпидемические заболевания для принятия в них необходимых против эпидемии мер; он должен оказывать врачебную помощь на дому более тяжелым больным и роженицам. Вести санитарный надзор за школами, следить за ходом оспопрививания на своем участке и заботиться о распространении гигиенических знаний и о проведении всякого рода санитарных мероприятий во всех селениях, входящих в состав его участка» [11,с. 113-114].

3 міською реформою 1870 р., наслідком якої стало територіальне розмежування сфер діяльності міського самоврядування і земств повітів, пов'язано створення фельдщерських та лікарських дільниць.

Система земської медицини повіту була реорганізована, центр діяльності був перенесений на сільську місцевість, стала складатися однакова дільнично-стаціонарна система медичного обслуговування населення.

Якщо у 1870 р. у Росії було 530 земських дільниць з середньою площею 4860 кв. верств на одну дільницю, де мешкало 95 тис. жителів, то у 1910 р. 2686 дільниць на 930 кв. верст та 28 тис. осіб [11,с. 121].

У 70-ті pр. повіти були розділені на 2-4 ділянки залежно від території і фінансових можливостей земства повіту. У центрі ділянки були побудовані земські лікарні з приймальними покоями і аптекою, якими завідував дільничний земський лікар, що проживав в центрі ділянки. При лікареві знаходився штат з 1-2 фельдшерів, акушерки, фармацевта (аптекаря).

У віддалених селах ділянки були влаштовані фельдшерські пункти із спеціальним фельдшером.

Земства повітів взяли на себе квартирні і роз'їзні витрати земських лікарів i фельдшерів, навчання і утримання їх учнів, будівництво і фінансування лікарень, аптек, витрати на амбулаторне і стаціонарне лікування хворих, забезпечення населення безкоштовними ліками. Асигнування на медицину склали в середньому 25,2\% усього бюджету земств.

Питання попередження епідемій i розвитку санітарії обговорювалися i вирішувалися земствами повітів паралельно з питаннями розвитку охорони здоров'я.

Відсутність чіткого погляду на роль і систему організації земської санітарії, точних даних по санітарному стану на місцях стримували активність земств повітів і земських лікарів. Основними заходами земств повітів щодо попередження епідемій стали організація віспощеплення населенню, виявлення вогнищ захворювання сифілісом, заходи щодо медичного огляду прийшлих сезонних робітників Донбасу.

В 1872 р. у Бахмуті засновано «приймальний покій». В рік обслуговували 5853 пацієнтів. Працювали лікар з окладом 85 руб., 4 фельдшери, акушерка, 2 віспощепії, 3 ветеринарні лікарі. Кошти йшли на «купівлю медикаментів для бідних, придбання інструментів, віспяного детриту, дифтерійної сироватки». Було побудовано відділення для інфекційних хворих. На приймальний покій через рік (1 лікар, 1 фельдшер, 1 акушерка, 1 віспощепій) було витрачено 500 руб. на ліки для 7620 хворих [14;15].

У 1875 р. для Бахмутської лікарні відійшла будівля від колишнього «Наказу суспільного піклування». Цим же часом датуються відомості про придбання у купця Анісимова будинку за 12 тис. руб. При лікарні були контора, квартира доглядача і провізора Нейяра. На другому поверсі розміщувалися чотири чоловічі палати, служниця, на першому поверсі - чотири жіночі палати, лабораторія, операційна, кімната лікаря і служителів, бібліотека. Опалювалася лікарня 32 печами 3 камінами [15].

В 1875 р. в лікарні перебувало 649 пацієнтів, з них 99 страждали венеричними хворобами. Сифілісом вражалися «шкіра, м'які тканини і кісткова система». Це вказує 
на велике число вродженого сифілісу. Первинні прояви сифілісу знаходили вкрай рідко. Запущені форми сифілісу зустрічалися у селян повіту, в сім'ях хворіло по декілька осіб, зараження відбувалося на побутовому рівні. Первинні форми сифілісу виявлялися у найманих робітників Бахмуту. Сифілісом були вражені багатодітні єврейські бідні родини [15].

На утримання 1 хворого в день витрачалося 60-65 коп.

В 1886 р. в лікарні було 45 ліжок, але взимку бувало до 67 пацієнтів. Працювали лікар, 2 фельдшери, фельдшерка і учень фельдшера, провізор, доглядач, конторщик, 7 служителів, 2 пральки, куховарка і наглядач [16].

В новій будівлі і в господарських спорудах розташовувалися контора, аптека, кухня, лазня і ванна кімнати, пральна, покійницька. Будівля опалювалася 13 печами 3 камінами.

Бахмутська лікарня у 1895 р. мала кошторис [17]:

Всі витрати

6346 руб

ремонт

184 руб.

прання білизни

346 руб

медикаменти, перев'язувальнізасоби, інструменти 10190 руб.

придбання віспяного детриту 811 руб.

зарплата лікарів, фельдшерів, акушерок повіту 14334 руб.

Лікарні міста в 1895 р. [17]:

пролікували померло

Земська лікарня $\quad 610 \quad 52$

Тюремна 82

Духовного училища 105

Для осіб, що не проживали в повіті, платня за лікування складала 10 руб., приблизно 40 коп. на добу.

Амбулаторію - Олександрівський приймальний покій відвідало 17.585 осіб. Прийом поліклінічний вівся і в самій земській лікарні.

В штаті Бахмутської земської лікарні були в 1895 р.: завідуючий Орест Лукич Шкляревський, з окладом 1200 рублів; лікар-ординатор Я.А. Смоленський; старший фельдшер Северин Нарцисович Жолкевський, що закінчив Харківську школу фельдшерів в 1894 р., з окладом 420 руб.; фельдшер Федір Юхимович Рудников, що закінчив школу фельдшерів в 1895 р., 3 окладом 300 руб.; фельдшер-акушерка Анастасия Дмитровна Дегтярьова, що закінчила школу фельдшерів у 1892 р. [17].

Норми їжі одного хворого в день в Бахмутській лікарні становили м'яса телятини 200 гр. або яловичини 400 гр, або 1/ 2 тушки курки, риби 400 гр, картоплі 200 гр, капусти 100 гр, масла рослинного, коров'ячого, жиру по 50 гр, гречки або пшона по 200 гр, хліба пшеничного до 1 кг. , цукру 4 шматки [17].

Такий рівень харчування міг навіть перевищувати денну норму харчування пацієнтів у побутовому житті.

В 1900 р. Земська лікарня мала 100 ліжок, працювали два городові лікарі, в штаті Земської управи було три лікарські ставки. Один лікар обслуговував залізничників, чотири лікарі були приватно практикуючими [18].

Розвиток стаціонарної допомоги у Маріуполі відбувався дещо повільніше, ані ж у Бахмуті.

Для Маріупольської земської лікарні були зібранні кошти ( згадка Отчет Мариупольский уездной земской управы за 1882 г. - Мариуполь : тип. Франтова, 1883), 
« был составлен приговор городского общества...пожертвованных на постройку здания для больницы 10310 руб. , Мариупольская Дума 9 марта 1867 года в виду настоятельной необходимости в скорейшем учреждении больницы, Александровское уездное земское собрание 26 сентября 1870 г. поручило ...управе приступить к постройке больницы...Управа решила открыть больницу в наемном помещении...был нанят дом Даниловой за 1000 р. в год в 1874 г. Но означенный дом не удовлетворял назначению: с одной стороны неподалеку находилось болото, с другой - базарная площадь; здание сыро, штукатурка обваливалась массами, не только стены, потолки во многих местах были покрыты постоянной влагой и цвелью, по отношению к распределению палат, помещению больничных принадлежностей и по удобству... здание не соответствовало понятию о больнице». Лікарня перебувала у кількорх різних будинках «Калери на углу Торговой и Митрополитской, А.И. Чабаненко, что на Георгиевской улице ...не могла найти помещения, удовлетворявшего назначению больницы».

Загальний кошторис будівництва лікарні становив 30 тис. руб., тому повітова управа у 1876 р. купила у Дяченко-Білого будинок за 11000 руб. «новый, о двух этажах, в шесть комнат каждый, с высокими потолками, с обширным дворовым местом, было посажено до 400 деревьев, неподалеку от общественного сада».

Було витрачено ще 2460 руб. на прибудови кімнат та флігель..

Но и при всем том помещение не удовлетворяло вполне своему назначению, почему Управа орендувала за 150 руб. на рік, а потім у 1878 р. придбала сусідній будинок у Єфімова за 3000 руб. и построила еще каменный флигель». У 1891 р. були добудовані льох, цейхгауз, два сараї, приміщення аптеки.

«В главном здании больницы: в верхнем этаже мужские палаты, контора смотрителя и комната для служителей; в нижнем этаже женские палаты, комната для фельдшеров и аптека. ..мужских палат пять, одна (называемая горячечной) служит для помещения в ней заразных больных, палаты носят особые названия (глазная, язвенная, общая большая и общая малая), женских палат три».

Головний лікар С.Ф. Гампер у 1890 р. відзначав «если бы придерживаться строго даже минимума того объема воздуха, который требуется гигиеной для каждого больного (50 куб. метров), то в больнице можно было бы поместить только 15 человек; , по штату полагается 30 кроватей, на каждого больного приходится 25 куб. метров воздуха, когда больных дойдет до 45-50 человек, то на каждого придется по 10-15 куб. метров воздуха, т.е. в пять раз меньше требуемой гигиеной минимума».

С.Ф.Гампер писав про недоліки лікарні: «отсутствие при больнице сестры милосердия и фармацевта; отсутствие особого помещения для ванн; отсутствие отдельного помещения для приема и осмотра приходящих больных и помещения, где бы они могли ожидать своей очереди (прием приходящих продолжается зачастую часа 2-3); отсутствие изолированных помещений для больных; отсутствие летних помещений для больных; отсутствие удовлетворительных приспособлений для дезинфекции вещей и белья заразных больных; отсутствие во дворе больницы хорошей помойной ямы, которую заменяет простая деревянная бочка; крайне необходимо значительное пополнение больничного белья, в котором теперь чувствуется постоянно недостаток; 9) необходимо произвести ремонт и окраску пола в больнице».

Опалювалася лікарня 14 печами на вугіллі, мала 12 гасових ламп, вентляції у стінах та вікнах.

Розраховувалася на 20 чоловічих іих 10 жіночих ліжок, але «наплыв больных бывает так велик, что принимается до 50 человек».

Лікарня утримувалася на кошти «назначаемые ежегодно из земских сборов, на деньги, выручаемые за пользование больных..., город постановил в помощь земству отпускать ежегодно по 1500 руб.», «земство отпускало на содержание больницы 3000 р. 
в год, затем 5000 р., но так как означенных средств не хватало, то ежегодно бывали передержки».

У 1881 р. на лікарню витрачено 10179 руб.. Через 10 років у 1890 р. - 12285 руб.

Земські збори вирішили, що « постоянные жители Мариупольского уезда пользуются бесплатно, жители других уездов или губерний платят в сутки 35 копеек. Виду стесненных обстоятельств, плата была повышена до 50 коп.; такая же плата взимается с жителей города, за лиц военного ведомства взыскивается плата, определяемая военным ведомством».

Кошти витрачалися таким чином: «продовольствие больных через смотрителя, мытье белья и снабжение водой с подряда, заготовление топлива, одежды, белья и предметов... управой».

У 1890 р. у лікарні працювали лікар, два фельдшери, фельдшерський учень, наглядач, кастелянша, три служителі, прислужниці, двірник, кухар, кухарський помічник.

Лікар отримував 1200 руб. на рік, наглядач - 400 руб. 3 квартирами, фельдшерам по 325 руб.

Склад хворих Маріупольської земської лікарні у 1881 і 1891 рр.

\begin{tabular}{|l|l|l|l|l|l|l|l|l|l|l|}
\hline & больн. & из уезда & $\begin{array}{l}\text { Из } \\
\text { города }\end{array}$ & $\begin{array}{l}\text { Иногоро } \\
\text { дн. }\end{array}$ & $\begin{array}{l}\text { Смбулато } \\
\text { Сн. } \\
\text { больные }\end{array}$ & Из уезда & $\begin{array}{l}\text { Из } \\
\text { города . }\end{array}$ & $\begin{array}{l}\text { Иногоро } \\
\text { дн. }\end{array}$ & Солдат \\
\hline 1883 & 589 & 222 & 50 & 203 & 114 & 738 & 183 & 358 & 179 & 18 \\
\hline 1890 & 679 & 267 & 44 & 312 & 56 & 2962 & 1046 & 951 & 940 & 56 \\
\hline
\end{tabular}

Треба зазначити, що спостерігалося зростання пацієнтів з повіту як вияв довіри до земської медицини.

3 метою отримання достатньої кількості сироватки для щеплення від чорної віспи у 1885 р. Маріупольське повітове земске зібрання постановило відткрити при лікарні телятник «риспособление обошлось в 27 руб., в нем могло поместиться не более трех телят... удалось достать девять телят. Для приготовления, хранения и рассыпки детрита были выписаны из Петербурга полный набор инструментов, камера и запас баночек на70 руб. Прививка началась 11 апреля, кончилась 4 июня. Первым телятам был привит детрит из Петербургского Вольно-Экономического Общества. Всего с 7-ми телят было собрано 244 баночки детрита. У 1891 р. лікар С.Ф.Гампер відзначав, що ««заготовление детрита прошло очень удачно: с шести телят было получено 447 баночек детрита; содержание телятника, так как из 6 телят два были предоставлены в пользование безвозмездно, обошлось дешевле в 20 руб., баночка детрита для прививки 30 человек, обошлась в 2 коп., тогда как рыночная цена баночки от 50 коп. до 1 руб.».

13 березня 1889 р. Маріупольська Дума вирішила почати будівництво міської лікарні. Було затверджено Опікунську раду з гласних І. Юрієва, П. Попова, Я. Пічахчі, О. Лапи , І. Лікаки, «смета на содержание 15 кроватей определена была в 8019 руб., отнесены 1500 руб., отпускаемых городом земской больнице, 500 руб., выдаваемых Благотворительному Обществу, 1500 руб. от пользования в больнице нижних чинов квартирующих в Мариуполе войск... Содержание больного в 1 руб. 12 коп.».

Дума вирішила орендувати будинок Данилових за 600 руб. «найден лучшим из всех, хотя по малопоместительности, неудобному расположению комнат, местоположению не удовлетворяет необходимым требованиям для больницы».

Лікарню відкрили 17 жовтня 1890 р. на 10 чоловічих и 5 жіночих. Працювали лікар І.Данилов (800 руб. на рік),, 2 фельдщери (по 300 руб.), доглядач (300 руб.), три служнтелі (190-120 руб.), кухар (180 руб.), праля (300 руб.) та сторож. 
Лікар І.Данилов відзначав, що лікарня «назначена исключительно для острых и заразных больных. Стационарных больных было 176 (124 чоловіків, 52 жінки), амбулаторных 484 (321 чоловіків,163 жінки)... г. Мариуполя 694, из уезда 74, без определенного места жительства 22, всего 790,мещан г. Мариуполя 428, дворян 2, чиновников 3, иногородних мещан и крестьян 288, военных 45, других званий 24».

У Маріуполі «еврейское общество стало подумывать об учреждении больницы, купчиха Е.Г. Авербах ... предложила дворовое место и дом для открытия больницы», але до початку XX століття лікарня не була відкрита.

У Бахмуті 16 червня 1901 року по вул. Мариупольській на гроші євреївпромисловців і купців А. Смоленського, М. Крамарєва, А. Гершковича, А. Фарбмана, М. Грінера, Е. Шухера, I. Голдріна, А. Французова, Я. Абрамовича відкрили Громадську лікарню. В Сврейській лікарні працювали Р.А. Шершевска - Розенфельд і O.I. Токарева [19].

Губернатор затвердив у 1912 р. залучення 6 тис. руб. 3 коробочного збору 3 євреїв на реконструкцію єврейської лікарні, ремонт будівлі, відбудову згорілих господарчих споруд. Багаті єврейки зібрали 2 тис. руб. та почали шиття білизни [20].

До губернатора відправили Статут лікарні. Готувалося обрання лікаря та підбор Господарською радою персоналу.

Одне крило було відведене для інфекційних пацієнтів. До травня були відкриті 10 безплатних ліжок [20].

У 1899 р. було відкрито нове приміщення Бахмутської лікарні, на що асигновано 29775 руб., на сифилисное відділення - 20306 руб. [21].

Заробітна плата у 1897 р. фельдшера Бахмутської лікарні становила 360 руб. в рік, тих, що прослужили 10 років і більш - 420 руб. в рік. 31902 оклади становили 420 і 480 руб. в рік, фельдшерам видавали квартирні гроші - 60 руб. в рік або надавали квартиру [21].

Оклад лікаря складав 800 руб. в рік, з 1875 р. - 1000 руб. в рік, з 1902 - 1200 руб. в рік і по вислузі років - 1500 руб. [21].

За 1900 р. лікувалося у міській лікарні 2194 хворих, амбулаторно 118 тис., у повіті діяло 7 лікарень.

В 1905-1906 pр. лікарні на придбання хірургічних інструментів було виділено 824 руб., на інвентар, придбання медикаментів і перев'язувального матеріалу - 1176 руб., на прання білизни — 1329 руб. [22].

Нова міська Бахмутська лікарня була побудована поряд з Земською Управою в $1908 \mathrm{p}$.

На будівництво лікарні в 1903 - 1908 рр. було асигновано 29775 руб., на сифилітичне відділення - 20306 руб. [23].

«Народна газета Бахмутського земства» в січні 1909 р. описувала Бахмутську земську лікарню- «на розі вулиць Великої Харківської і Вокзальної головний корпус лікарні з амбулаторією, аптекою і хірургічним відділенням. Вдалині за корпусом видно двоповерхову будівлю сифілітичного відділення, у дворі приміщення для заразних хворих, кухні, пральної, дезинфекційної камери. Корпуси для квартир персоналу і другого лікаря лікарні. Завідує лікар В.М. Стебельский спільно 3 лікарем В.А. Бервольфом, дільничний лікар лікарні О.В. Филіпьєв. Розрахована на 120 ліжок».

Лікарняний двір площею 3240 кв. сажнів був засаджений садом. Мала 3 будівлі: головний корпус на 50 ліжок соматичних хворих, 2-поверховий на 10 палат, що вміщали від 60 до 95 хворих. Операційна мала мозаїчні підлоги, пофарбовані стіни, баки для кип'ятіння води і каналізацію, освітлення газоліном. В 3-х шафах знаходилися інструменти, був операційний стіл Гана, 2 дерев'яні столи, табурети, підставки під емальовані тази, бікси. Передопераційна була обладнана 2 автоклавами, дезкамерою, 
стерилізаторами для інструментів, машиною для виготовлення бинтів. Дві операційні палати були відокремлені від решти соматичних [22].

В соматичному відділенні була своя перев'язувальна 3 операційним столом.ях , про що є доповідь 3'їзду гірничоо-заводських лікарів у Харкові.Через поганий тиск у водогоні воду нерідко доставляли кінними бочками. Господарчі споруди лікарні складалися 3 будівлі кухні, сараю, 4-х льохів, льодовика.Будівля терапевтичного відділення одноповерхова, мала 3 палати. Інфекційне відділення 2-поверхове на 4 чоловічих і 3 жіночі палати на 16-22 пацієнтів [22].

Для сифілітиків був окремий корпус 2-х поверховий на 40 ліжок (11 палат).Квартири медперсоналу розташовувалися в 3-х будівлях (для лікаря, провізора, фельдшерів).

У лікарні 1 лікар мешкав у квартирі лікарні, 2 лікаря мали по 400 руб. на оренду житла. В.М.Стебельський відзначав, що «акушеркам потрібні ванни при їх діяльності».

Лікарняна аптека займала 3 великі кімнати і в напівпідвалі була лабораторія, кімната «кокторіїв», пакувальна, мийна. Провізором бахмутскої земської лікарні був Федір Францевич Владиславський, закінчив Харківський університет в 1895 р., помічником провізора працював Олександр Соломонович Остроухов, атестований у Харкові в 1896 році.

Оклад провізора дорівнював 620 руб., помічника 360 руб. В 1913-1914 рр. планувалося будівництво нового приміщення, працювали провізор, 7 аптечних помічників, що готували ліки, 3 служителі складали сигнатури, контролювали склад препаратів, ліків. Були лаборант, 2 фельдшери і 3 учні [22].

Щодня з ранку аптека протягом 3-х годин відпускала до 300 назв ліків для стаціонару, а також по рецептах лікарів Приймального покою. В лікарняну аптеку медикаменти поступали від фірми Юротата з Києва, посуд від Глінського з Ростову, папір і спринцівки від Гофмана з Харкова, термометри з Москви .

В січні 1911 р. Бахмутська Дума заслухала доповідь санітарного лікаря повіту В.П. Фіалковського «Про поліпшення санітарної організації у Бахмуті». Лікар відзначав: «відомості про тривалість життя городян - 26,5 років (загальноросійська - 33 роки, в Бельгії - 45-50 років), амбулаторію відвідують до 20 тисяч осіб на рік, захворює інфекціями 1800 осіб, 334 хворих, як правило, один помирає, середня тривалість хвороби складала у той час 20 днів.

В.П. Фіалковський відзначав, що «внаслідок хвороб було втрачено 579200 робочих днів».

В 1912 р. Бахмутська Дума побудувала нове амбулаторне відділення вартістю 15 тис. руб., де працювали два лікарі і фельдшер: на амбулаторний прийом звернулося 26 тисяч жителів (більше, ніж мешкало у місті), було витрачено на утримання амбулаторії 4 тис. руб., одні відвідини хворого коштували 15 коп. [24].

Головний лікар Бахмутської лікарні (1908-1920рp.) В. М. Стебельський народився в сербському селі Калинівка Бахмутського повіту в 1860 р. Після закінчення Таганрозької гімназії вчився на медичному факультеті Московського університету, його залишав у себе на кафедрі хірургії, акушерства і гінекології професор В.О. Снегірьов. Але В.М. Стебельський став лікарем 2-ї ділянки Бахмутського повіту [25].

B.M. Стебельський відзначав про умови праці медиків бахмутської лікарні: «як квартири лікаря, так і фельдшерів дуже погані і малі.., дільничні лікарі мають розкішні квартири». Прислуга лікарні поміщалася на чергуваннях в 2-х маленьких кімнатах «при переповнюванні хворими персонал фельдшерів, палатна прислуга перевтомлюються після нічних чергувань і операцій».

При 100 штатних ліжках лікарня мала наповнюваність до 130-140 хворих. Обходи проводилися щодня вранці лікарем і фельдшерами, 2 дні в тиждень були 
операційними, чергування у прооперованих хворих велося цілодобово. Лабораторія лікарні робила аналізи крові, мокроти, шлункового вмісту [26]. працював.

Через відсутність до 1913 року електрики у Бахмуті рентгенівський кабінет не

У Бахмуті у 1914 р. працювали 15 лікарів на 20 тисяч жителів (12 з них займалися приватною практикою), навантаження на одного лікаря складало 2355 жителів.

Висновок. Вивчення матеріалів діяльності Бахмутського, Маріупольського повітових земств, міських Дум дозволяє зробити висновок про те, що створення міської мережі лікарень було зобов'язане благодійності земських діячів. Завдяки наполегливості земчьких гласних з різних станів Донеччини, постійному фінансуванню лікарні мали сучасне обладнання, кваліфіковані медичні кадри, добре харчування та безкоштовні ліки для пацієнтів.

Література:

1. Ленин В.И. Полное собрание соч./В.И.Ленин// -т. 5.

2. Осипов Е.А., Попов И.В., Куркин П.И. Русская земская медицина/Е.А.Осипов//. Обзор развития земской медицины в России и Московской губернии. - М., - 1899. 1888.

3. Абрамов А.В. Что сделало земство и что оно делает /А.В.Абрамов//. - СПб., -

4. Веселовский Б.Б. История земства за сорок лет/Б.Б.Веселовский// В 4-т. СПб., -1909-1911; Львов Г.Е.,Полнер Т.И.. Наше земство и 50 лет его работы/Г.Е.Львов//. - М., - 1914.

5. Игумнов С.Н. Очерк развития земской медицины в губерниях вошедших в состав УССР /С.И.Игумнов//. - К., - 1940.

6. Матеріали до історії розвитку охорони здоров'я на Україні. Під ред. к.м.н. К.Ф.Дупленко. - К., - 1957.

7. Голяченко А.М. К развитию земской медицины на Украине/А.М.Голяченко // Советское здравоохранение. - 1966. - №1. - С. 66-70; Межиров Л.С. К истории развития медицинской помощи промышленным рабочим Украины в н. XX века/ Л.С.Межиров // Советское здравоохранение. - 1972. - № 8. - С. 72-76;; Милявский В.М Общество полтавских врачей и Труды постоянной медицинской комиссии при Полтавской губернской управе/В.М.Милявский // Советское здравоохранение. - 1981. №4. - С.69-71

8. Маскина А.С. Таврическое земство в 1866 - 1890 гг. (Социальный состав, бюджеты и практическая деятельность)/А.С.Маскина//: Автореф. дисс. ... канд. ист. наук. - М., -1982; Зубко А.Н. Материалы земской статистики как исторический источник по изучению истории Украины периода капитализма /А.Н.Зубко//. Автореф. дисс. ... канд. ист. наук. - К., - 1988; Сессак И.В. Земские учреждения на Правобережной Украине/И.В.Сесак//. Автореф. дисс. канд. ист. наук. - Львов, - 1987 т

9. Чернобров И.В. Хирургия на Сумщине /И.В.Чернобров// Проблемы социальной гигиены, здравоохранения и истории медицины. - 1999. - №5. - С.59-60; Поляк М.С., Каменецкий М.С. 3 історії розвитку рентгенології в Донбасі /М.С.Поляк // Український радіологічний журнал. - 1996. - №2. - С. 211-214;

10. Лохматова А. Катеринославське земство: соціальний склад, бюджет та практична діяльність. 1866-1913 pp./А.А.Лохматова// Автореф. дис... канд. іст. наук. - Запоріжжя, 1994; Цибуленко Л.О. Діяльність органів самоврядування Одеси, Миколаєва. Херсона щодо формування і розвитку муніципальної земельної та виробничої власності в кінці XIX - на початку XX століття / Л.О.Цибуленко//. Автореф. дис... канд. іст. наук - Дніпропетровськ, 2001; Обметко О.М. Соціально-економічна діяльність земств в Україні (середина 60-х - 90-х 
років XIX ст.) /О.М.Обметко// - Автореф. дис... канд. іст. наук. - Київ, -2002 Рубан Н. М. Розвиток земської медицини в Україні /Н.М.Рубан//.Автореф.дис. на здобуття наукового ступеня канд. іст. наук. Донецьк, - 2004.

11. Френкель 3. Г. Очерки земского врачебно-санитарного дела /3.Г.Френкель//. - СПб., - 1913.

12. Материалы для географии и статистики России, собранные офицерами Генерального Штаба: Екатеринославская губерния. //Составил Генерального Штаба капитан В.Павлович. - Санкт-Петербург: Типография Департамента Генерального Штаба, - 1862,

13.Памятная книжка Екатеринославской губернии на 1864 год. - Екатеринослав; РГИА. - Ф. 1281. - Оп. 7. - Д. 51. 22 Ведомость города Бахмута за 1865 год из отчета Екатеринославского губернатора; Памятная книжка Екатеринославской губернии на 1867 год. - Екатеринослав, - 1867.

14.Отчет Бахмутской уездной земской управы за 1870 год к $\mathrm{V}$-му очередному земскому собранию. -Бахмут, $-1871,-51$ с.; Отчет Бахмутской уездной земской управы с 1-го января 1875 по 1-е января 1876 года XI очередному земскому собранию. Бахмут, -1876. - 91 с.

15. Отчет Бахмутской уездной земской управы с 1 августа 1881 года по 1 августа 1882 года. - Бахмут, - 1882. - 140 с.

16. Доклады Бахмутской уездной земской Управы и журналы XX очередного собрания. -Бахмут, $-1886 .-370$ с.

17.Доклады Бахмутской уездной земской Управы и журналы XXIX очередного собрания. - Бахмут, - 1895. - 418 с.

18.Доклады Бахмутской уездной земской Управы и журналы XXXVI очередному собранию. - Бахмут, -1901. - 64 с.

19.Татаринов С.И., Федотов С.А. Штетл Бахмут. - Харьков:Слово, - 2013, -185 с.

20. Бахмутский листок, апрель 1912

21.Отчет Екатеринославской губернской земской управы за 1900 г. Часть вторая. - Екатеринослав : Тип. Губернского земства, - 1901; Отчет Екатеринославской губернской земской управы за 1901 г. Часть вторая. - Екатеринослав : Тип. Губернского земства, -1903

22. Развитие медицины Бахмутского уезда в 1909-1913 гг. - Бахмут. - 1913. -624 c.

23. Денежный отчет Бахмутской городской Думі за 1905 год. \Ч.2\; Денежный отчет. 1906. - 90 с.; РГИА. -Ф.1290. - Оп.5. -Д.230.Анкета статистических сведений о состоянии города Бахмута за 1900-1909 гг.

24. Отчет Бахмутской городской управы за 1910 год. -Бахмут, - 1911. - 105 с.(РНБ,шифр 19.49.4.140); Отчет Бахмутской городской управы за 1913 год. -Бахмут, 1914. - 123 с. (РНБ,шифр: 17.160.6.95)

25. Татаринов С.Й., Завада Л.В., Блєднов В.П. Нариси земської медицини Бахмутського повіту /С.Й.Татаринов//. - Артемівськ, - 2011, - 86 с.

26. Екатеринославский губернский съезд земских врачей. Труды ХІ губернского съезда. - Екатеринослав, -1914 